Original Research Article

\title{
A study to assess awareness amongst pregnant women about the effects of drugs on the fetus and self-medication
}

\author{
Neeta Banzal*, Kirti Saxena, Malti Dalal, S. K. Srivastava
}

\begin{abstract}
Department of Pharmacology, Surat Municipal Institute of Medical Education and Research, Surat, Gujarat, India
\end{abstract}

Received: 30 January 2017 Accepted: 14 February 2017

\section{*Correspondence to:}

Dr. Neeta Banzal,

Email: akj01936@yahoo.com

Copyright: (c) the author(s), publisher and licensee Medip Academy. This is an openaccess article distributed under the terms of the Creative Commons Attribution NonCommercial License, which permits unrestricted noncommercial use, distribution, and reproduction in any medium, provided the original work is properly cited.

\begin{abstract}
Background: The present study was conducted with an objective to assess the awareness of drug use in pregnancy, to assess the knowledge of pregnant women on effect of drugs on foetus and to assess the self-medication among pregnant women.

Methods: This was a prospective, observational, cross-sectional study conducted on randomly selected 200 pregnant women attending a tertiary care hospital in Surat, Gujarat, India. Data was collected by means of a pre-designed semi-structured questionnaire composed of 26 questions on self-medication during pregnancy and knowledge about that. The data was collected by interview technique in which each participant was asked questions in the language of her understanding in a separate room.

Results: The average age of the participants was $23.7 \pm 3.68$ years. About $91 \%$ were not aware about the effect of medication on the health of foetus and did not even enquire about it. At the time of survey, $74 \%$ pregnant women were on some kind of medication. More than $80 \%$ were not aware about the duration of medication. About $51 \%$ were taking medication on regular basis. The proportion of self-medication among pregnant women was $8.5 \%$ (includes $5.5 \%$ by themselves and $3 \%$ by advice of chemists).

Conclusions: There is a lack of awareness amongst the pregnant women regarding the effect of the drugs on the health of foetus. More than half of the women take medication on regular basis. However, low proportion of selfmedication during pregnancy suggests that during pregnancy women preferred to take advise of physician for medication rather than taking self-medication.
\end{abstract}

Keywords: Drug Safety, Foetus, Pregnancy, Self-medication

\section{INTRODUCTION}

Pregnancy is a normal physiological phenomenon and illness during pregnancy is not uncommon. Certain problems are physiological for example nausea, vomiting, anemia, constipation etc.

Drug prescribed during pregnancy may produce side effects \& it also affects fetus particularly first trimester when organogenesis takes place. This is because placenta is incomplete barrier so most of the drug crosses this barrier. The effect of drugs on fetus may range from minor problem to very serious congenital anomaly i.e. teratogenic effect. It has been found that there are physiological changes apart from anatomical defects. There are many examples for teratogenicity such as cleft lip, cleft palate, spina bifida and classical one is phocomelia due to thalidomide, the thalidomide disaster. ${ }^{1}$ Thus, the use of drugs during pregnancy should preferably be avoided except haematinics i.e. iron, folic acid certain vitamins. ${ }^{2-6}$ Folic acid also prevents neural tube defects apart from erythropoiesis. ${ }^{3}$ Since the consequences of the drug used during pregnancy may be serious and cause disability and burden to the family which may be lifelong. ${ }^{7}$

Many studies on drug utilization pattern during pregnancy are available worldwide including India. Almost all categories of drugs are prescribed during pregnancy depending on the illness. ${ }^{8-11}$ Mashayekhi et al have evaluated the awareness among pregnant women with regard to effect of drugs on fetus. ${ }^{12}$ Drug use 
behavior in pregnant women in rural India has been investigated. Self-medication during pregnancy is common. Earlier also, in a study from USA, OTC medication (e.g. ibuprofen) that are contraindicated in pregnancy were used at unexpectedly high rate during pregnancy. ${ }^{13}$ The other studies available have also shown high consumption of OTC drugs in pregnant mothers which may produce deleterious effect on fetus. ${ }^{14,15}$ During pregnancy utilization of OTC and herbal drugs was common. ${ }^{16}$ One study has shown that during pregnancy OTC and herbal drugs were used, however, folic acid was not supplemented in all the women, moreover, even iron was not prescribed in anemic pregnant women by the health care providers. ${ }^{17}$ This is due to lack of awareness and knowledge of effect of drugs on fetus among pregnant women.

The present study was conducted with an objective to assess the awareness of drug use in pregnancy, to assess the knowledge of pregnant women on effect of drugs on fetus and to assess the self-medication among pregnant women.

\section{METHODS}

This was a cross-sectional study conducted on randomly selected 200 pregnant women attending tertiary care hospital. The study was conducted in a tertiary care hospital in Surat, Gujarat, India. The inclusion criteria were all pregnant women attending antenatal clinic of a tertiary care hospital.

Data was collected by means of a pre-designed semistructured questionnaire composed of 26 questions. The questionnaire used was a modified form of a previously validated survey carried out by Nordeng et al, the modifications made in the questionnaire were discussed in the Obstetrics and Gynecology and Pharmacology department of SMIMER before administering the same to the participants. ${ }^{10}$ The questionnaire included the information regarding demographic profile of the participants, the type of the drugs they are taking, the symptoms in which they would like to consult a doctor, the symptom for which they will take self-medicated drug, awareness about the possible side-effects of the drugs and their beliefs and attitudes regarding medication use in general. The data was collected by interview technique in which each participant were asked questions in the language of her understanding in a separate room. Before conducting the study, the informed voluntary written consent of the patients was taken. They were informed that the confidentiality of information shall be maintained. The participation was voluntary. The approval of the Institutional Ethical Committee of SMIMER Surat was obtained before conducting the study.

The responses were noted as either agree and disagree. The frequency of various variables was calculated with the use of MS Excel software.

\section{RESULTS}

There were total 200 participants selected in the study. The average age of the participants was $23.7 \pm 3.68$ years. Not a single participant was below 18 years of age. It was evident from the Table 1 that more than $90 \%$ of the participants were in the age group of 18-29 yrs. Only one participant was of the age group 40 and above. Educational status of the participants was as shown in Table 1.

\section{Table 1: Socio-demographic profile of participants $(n=200)$.}

\begin{tabular}{|ll|}
\hline Variable & \multicolumn{1}{l|}{ Frequency (\%) } \\
\hline \multicolumn{1}{|l|}{ Age (years) } & \\
\hline $18-19($ Below 20) & $20(10)$ \\
\hline $20-29$ & $163(81.5)$ \\
\hline $30-39$ & $16(8)$ \\
\hline 40 and above & $01(0.5)$ \\
\hline Education & $168(84)$ \\
\hline Non-matriculate & $24(12)$ \\
\hline Matriculate & $08(4)$ \\
\hline Graduate & $166(83)$ \\
\hline Economic status (annual income in rupees) \\
\hline$<1$ lakh & $34(17)$ \\
\hline 1 to 3 lac & $11(5.5)$ \\
\hline Occupational status & $189(94.5)$ \\
\hline Employed & $198(99)$ \\
\hline House wives & $02(1)$ \\
\hline Medical System followed by pregnant women \\
\hline Allopathy & $00(0)$ \\
\hline Ayurvedic & \\
\hline Homeopathy & \\
\hline
\end{tabular}

The economic status of the patients was low income group (83\%, family earning less than INR 1 Lac) and lower middle income group (17\%, less than INR 3 Lacs, Table 1). This is as per expected lines as mostly lower or lower middle class are visiting state run hospitals. A very small percentage $(4.5 \%)$ total 9 out of 200 women were employed. On the question of their belief in indigenous system of medicine, all except one informed that they believe in Allopathic system.

It was seen that total $8.5 \%$ participants were taking selfmedication, $5.5 \%$ themselves and $3 \%$ participants were taking medication on the advice of chemists. Out of 200 patients, only $9 \%$ participants were aware about the effect of drug on the foetus during pregnancy.

It was found that $74 \%$ of participants were taking iron and folic acid supplements but only $38.5 \%$ participants were aware about the purpose of taking iron and folic acid supplement and only $16 \%$ were aware about the duration to which this supplement is to be taken (Table 2). There were only $51 \%$ of the participants who were taking these supplements on regular basis. 
Table 2: Awareness about medication and vaccination in pregnant women $(n=200)$.

\begin{tabular}{|ll|l|}
\hline Current medication & Yes (\%) & No (\%) \\
\hline $\begin{array}{l}\text { Taking any form of } \\
\text { medication }\end{array}$ & $148(74)$ & $52(26)$ \\
\hline $\begin{array}{l}\text { Awareness about purpose } \\
\text { of medication }\end{array}$ & $77(38.5)$ & $123(61.5)$ \\
\hline $\begin{array}{l}\text { Awareness about duration } \\
\text { of medication }\end{array}$ & $32(16)$ & $168(84)$ \\
\hline $\begin{array}{l}\text { Current medication with } \\
\text { advice of chemist for minor } \\
\text { problem }\end{array}$ & $6(3)$ & $194(97)$ \\
\hline $\begin{array}{l}\text { Patient taking self- } \\
\text { medication off and on }\end{array}$ & $11(5.5)$ & $189(94.5)$ \\
\hline $\begin{array}{l}\text { Patient taking medication } \\
\text { regularly }\end{array}$ & $102(51)$ & $98(49)$ \\
\hline $\begin{array}{l}\text { Knowledge about effect of } \\
\text { drugs on the foetus during } \\
\text { pregnancy }\end{array}$ & $18(9)$ & $182(91)$ \\
\hline $\begin{array}{l}\text { Awareness about purpose } \\
\text { of vaccination }\end{array}$ & $103(51.5)$ & $97(48.5)$ \\
\hline $\begin{array}{l}\text { Awareness about safety of } \\
\text { vaccination }\end{array}$ & $64(32)$ & $136(68)$ \\
\hline
\end{tabular}

Only $51.5 \%$ were aware about the purpose of tetanus vaccination (Table 2). However it was found that only $32 \%$ participants were aware that taking such vaccination is safe during pregnancy.

\section{DISCUSSION}

The decision of drug administration by the pregnant women depends on access and availability of drug related information and on beliefs about the medication during pregnancy. In the present study, $10 \%$ of the participants were in the age group below 20 years which is quite comparable to the study conducted by Abasiubong et al in which $8.7 \%$ were in the age group below 20 years. ${ }^{18}$ However, in the study conducted by Abasiubong et althere were $44.6 \%$ and $41.3 \%$ were in the age group of 20-29 years and 30-39 years respectively which amounts to $85.9 \%$ in the age group of 20-39 years compared to present study where total $89.5 \%$ in the age group of 20 39 years. ${ }^{18}$ However, in the present study there are $81.5 \%$ in the age group of 20-29 and only $8 \%$ in the age group of 30-39. The high percentage in the age group 20-29 years may be due to the fact that in Indian environment the marriages happen at an early age and there is a social pressure to have children at relatively early in the marriage. In the present study $84 \%$ cases had studied below $10^{\text {th }}$ standard (non-matriculate). The educational level of the participants in present study were lower than that of Abasiubong et al study in which total $73.2 \%$ had studies upto secondary education $(9.9 \%$ no education, $19.5 \%$ participants were studied upto primary education and $43.8 \%$ had taken secondary education). ${ }^{18}$ As previously shown in other communities, sociodemographic factors, such as education, occupation and local beliefs may have a significant impact on patients' attitudes and beliefs toward medications. ${ }^{19}$

In our study only $8.5 \%$ participants were using selfmedication. In Abasiubong et al study, about $25 \%$ and $35 \%$ of the pregnant women with higher level of education used analgesics and antibiotics respectively. ${ }^{18}$ This, when compared with $6.9 \%$ and $12.0 \%$ of them with low level of education involved in the use of the same substances, is very significant. These findings seem to suggest that the level of self-medication is less in less educated class. This finding is also supported by the study carried out by Adhikari et al on pregnant women in rural India where a high level compliance (97.7\%) was observed in socioeconomically backward group which tend to follow the doctor's advice rather than going for self-medication. ${ }^{20}$ In another study carried out by Gharoro and Igbafe et al the use of self-medication in the form of native herbal drug was found to be $12.08 \%$ which is quite close to finding of present study. ${ }^{21}$

In the present study, $74 \%$ of participants were taking iron and folic acid supplements but only $38.5 \%$ participants were aware about the purpose of taking iron and folic acid supplement. Only 51\% were taking these supplements on regular basis. However, more than $90 \%$ participants were not aware regarding the effect of drug on the foetus. The beliefs about medication decide patient's compliance or adherence to a certain medication. ${ }^{22}$ This is even more important in context to pregnant women. ${ }^{23}$ Whenever they are faced with the decision on whether or not to use medication during pregnancy, the choice depends on multiple factors including possible benefits or side-effects to her and her child, her education level and her socio-economic status.

\section{CONCLUSION}

There is a lack of awareness amongst the pregnant women regarding the effect of the drugs on the health of foetus. More than half of the women take medication on regular basis. However, low proportion of self-medication during pregnancy suggests that during pregnancy women preferred to take advice of physician for medication rather than taking self-medication.

\section{Funding: No funding sources}

Conflict of interest: None declared

Ethical approval: The study was approved by the Institutional Ethics Committee

\section{REFERENCES}

1. Banhidy F, lowry RB, Czeizel AE. Risk and benefit of drug use during pregnancy. Int $\mathrm{J}$ Med Sci. 2005;2:100-6.

2. Deborah E, McCarter, Spaulding MS. Medications in pregnancy and lactation. Amer J Maternal Child Nursing. 2005;30:10-7. 
3. Bestwick JP, Huttly WJ, Morris JK, Wald NJ. Prevention of neural tube defects: a cross-sectional study of the uptake of folic acid supplementation in nearly half a million women. PLoS ONE. 2014;9:e89354.

4. Tort J, Lelong N, Prunet C, Khoshnood B, Blandel B. Maternal and health care determinants of preconceptional use of folic acid supplementation in France: results from the 2010 National Perinatal Survey. BJOG. 2013;120:1661-7.

5. Ma GA, Schouten EG, Ye Sun Y, Yang F, Xia Han $\mathrm{X}$, Zhi Zhang $\mathrm{F}$ et al. Supplementation of iron alone and combined with vitamins improves haematological status, erythrocyte membrane fluidity and oxidative stress in anaemic pregnant women. Br J Nutr. 2010;104:1655-61.

6. Harville EW, Schramm M, Watt-Morse M, Chantala $\mathrm{K}$, Anderson JJ, Hertz Picciotto I. Calcium intake during pregnancy among white and AfricanAmerican pregnant women in the United States. J Am Coll Nutr. 2004;23:43-50.

7. E Hajiseidjavadi. Knowledge of pregnant women on drug use during pregnancy. J Qazvin Univ Med. Sci. 2005;9:3:80-83.

8. Daw JR, Hanley GE, Greyson DL, Morgan SG. Prescription drug use during pregnancy in developed countries: a systematic review. Pharmacoepidemiol Drug Saf. 2011;20(9):895-902.

9. Sharma R, Kapoor B, Verma U. Drug utilization pattern during pregnancy in North India. Indian $\mathrm{J}$ Med Sci. 2006;60:277-87.

10. Nordeng H, Koren G, Einarson A. Pregnant women`s beliefs about medications-a study among 866 Norwegian women. Ann. Pharmacother. 2010;44(9):1478-84.

11. Zhu X, Qi X, Hao J, Huang Z, Zhang Z, Xing X, et al. Pattern of drug use during the first trimester among Chinese women. Eur J Clin Pharmacol. 2010;66-511-8.

12. Mashayekhi SO, Dilmaghanizadeh M, Fardiazar Z, Bamdad-Moghadam R, Ghandforoush-Sattari F. Study of awareness among pregnant women of the effects of drugs on the fetus and mother in Iran. Health Policy. 2009; 91(1):89-93.

13. Glover DD, Amonkar M, Rybeck BF, Tracy TS. Prescription over-the-counter and herbal medicine use in a rural, obstetric population. Am $\mathrm{J}$ Obstet Gynecol. 2003;188:1039-45.

14. Drhova L. Knowledge, attitudes and behavior of the population of the Czech Republic to self-medication -II. Knowledge of and information about drugs. CeskaSlov Farm. 2005;54:168-72.

15. Black RA, Hill DA. Over-the-counter medications in pregnancy. Am Fam Physician. 2003;67(12):2517-24.

16. Kebede B, Gedif T, Getachew A. Assessment of drug use among pregnant women in Addis Ababa, Ethiopia. 2009;18(6):462-8.

17. Sawalha AF. Consumption of Prescription and nonprescription medications by pregnant women: a cross sectional study in Palestine. The Islamic Univ J. 2007;15(2):41-57.

18. Abasuibong F, Bassey EA, Udobong JA, Akinbami SO, Udoh SB, Idung AU. Self-medication: Potential risk and hazard among pregnant women in Uyo, Nigeria. Pan Afr Med J. 2012;13:15.

19. Mardby AC, Akerlind I, Jorgensen T. Beliefs about medicines and self-reported adherence among pharmacy clients. Patient Educ Couns. 2007;69:158164.

20. Adhikari A, Biswas S, Chattopadhyay JC, Gupta RK. Drug use behaviour of pregnant women in rural India. J Pak Med Assoc. 2011;61(4):381-3.

21. Gharoro EP, Igbafe AA. Pattern of drug use amongst antenatal patients in Benin City, Nigeria. Med Sci Monit. 2000;6(1):84-7.

22. Saks EK, Wiebe DJ, Cory LA, Sammel MD, Arya LA. Beliefs about medications as a predictor of treatment adherence in women with urinary incontinence. J Womens Health (Larchmt). 2012;21:440-6.

23. Emilsson M, Berndtsson I, Lotvall J, Millqvist E, Lundgren J, Johansson A et al. The influence of personality traits and beliefs about medicines on adherence to asthma treatment. Prim Care Respir J 2011;20:141-7.

Cite this article as: Banzal N, Saxena K, Dalal M, Srivastava SK. A study to assess awareness amongst pregnant women about the effects of drugs on the fetus and self-medication. Int J Basic Clin Pharmacol 2017;6:924-7. 